\title{
Creating a Framework for Sovereign Debt Restructuring That Works
}

Martin Guzman and Joseph E. Stiglitz

Debt matters. In recessions, high uncertainty discourages private spending, weakening demand. Resolving the problem of insufficient demand requires expansionary macroeconomic policies. But "excessive" public debt may constrain the capacity for running expansionary policies. ${ }^{\mathrm{I}}$ Evidence shows that high public debt also exacerbates the effects of private sector deleveraging after crises, leading to deeper and more prolonged economic depressions (Jordà, Schularick, and Taylor, 2013).

Even if programs of temporary assistance (e.g., from the International Monetary Fund) make full repayment of what is owed possible in those situations, doing so could only make matters worse. If the assistance is accompanied by austerity measures, it would aggravate the economic situation of the debtor. ${ }^{2,3}$

Distressed debtors need a fresh start, not just temporary assistance. This is in the best interests of the debtor and the majority of its creditors: precluding a rapid fresh start for the debtor leads to large negative-sum games in which the debtor cannot recover and creditors cannot benefit from the larger capacity of repayment that the recovery would imply.

Lack of clarity for resolving situations in which a firm or a country cannot meet its obligations can lead to chaos. There can be extended periods of time during which the claims are not resolved and business (either of the firm or the country) cannot proceed-or at least cannot proceed in the most desirable way. In the meantime, assets may be tunneled out of the firm or country, or at the very least, productive investments that would enhance the value of the human and physical assets are not made.

Within a country, bankruptcy laws are designed to prevent this chaos, ensuring an orderly restructuring and discharge of debts. Such 
laws establish how restructuring will proceed, who will get paid first, what plans the debtor will implement, who will control the firm, and so on. Bankruptcies are typically resolved through bargaining among the claimants-but with the backdrop of a legal framework and with a judiciary that will decide what each party will get, based on well-defined principles.

Bankruptcy laws thus protect corporations and their creditors, facilitating the processes of debt restructuring. A more orderly process not only lowers transactions costs but precludes the deadweight losses associated with disorderly processes; in doing so, it may even lower the cost of borrowing.

Good bankruptcy laws facilitate efficient and equitable outcomes in other ways; for instance, in encouraging lenders to undertake adequate due diligence before making loans.

The benefits of a legal framework providing for orderly debt restructuring have also been extended to public bodies, for instance, through Chapter 9 of the U.S. Bankruptcy Code.

But there is no comprehensive international bankruptcy procedure to ensure proper resolution of sovereign debt crises. Instead, the current system for sovereign debt restructuring (SDR) features a decentralized market-based process in which the debtor engages in intricate and complicated negotiations with many creditors with different interests, often under the backdrop of conflicting national legal regimes. Outcomes are often determined on the basis not of principles but of economic poweroften under the backdrop of political power. Restructurings come too little, too late. ${ }^{4}$ And when they come, they may take too long. ${ }^{5}$ The lack of a rule of law leads to ex ante and ex post inefficiencies and inequities both among creditors and between the debtor and its creditors.

Furthermore, unlike domestic bankruptcies, sovereign bankruptcy negotiations take place in an ambiguous legal context. Several different jurisdictions, all with different perspectives, influence the process. Different legal orders often reach different conclusions for the same problem. It may not be clear which will prevail (and possibly none will prevail) and how the implicit bargaining among different countries' judiciaries will be resolved.

At the time we write this chapter, events are making the reform of the frameworks for SDR a major issue. Countries in desperate need of addressing profound debt sustainability issues, like Greece at the moment, are confronting the risks of a chaotic restructuring, and this discourages 
them from undertaking the restructurings that are now recognized as desirable or even inevitable.

Besides, the gaps in the legal and financial international architecture favor behavior that severely distorts the workings of sovereign lending markets. The emergence of vulture funds-investors who buy defaulted debt on the cheap and litigate against the issuer, demanding full payment and disrupting the whole restructuring process - as recently seen in the case of Argentine restructuring, is a symptom of a flawed market-based approach for debt crisis resolution.

Recent decisions $s^{6}$ have also highlighted the previously noted interplay among multiple jurisdictions, none of which seems willing to cede the right to adjudicate restructuring to the others (Guzman and Stiglitz, 2015b).

There is consensus on the necessity of moving to a different framework, but there are different views on the table about how to move forward.

The International Monetary Fund (IMF) and the financial community represented by the International Capital Markets Association (ICMA) recognize that the current system does not work well (ICMA, 2014; IMF, 2014). They are proposing modifications in the language of contracts, such as a better design of collective action clauses (CACs) and clarification of pari passu-a standard contractual clause that is supposed to ensure fair treatment of different creditors. These proposals are improvements over the old terms, but they are still insufficient to solve the variety of problems faced in SDRs. And it is almost surely the case that new problems will arise-some anticipated, some not-within the new contractual arrangements.

On the other hand, a large group of countries is supporting the creation of a multinational legal framework, as reflected in Resolution $69 / 304$ of the General Assembly of the United Nations of September 2014, which was overwhelmingly passed (by I24 votes to II, with $4 \mathrm{I}$ abstentions), and more recently in Resolution 69/L.84 of September 2015 that established a set of principles that should be the basis of a statutory framework for sovereign debt restructuring, passed with 136 votes in favor, $4 \mathrm{I}$ abstentions, and only 6 against (see $\mathrm{Li}, 2015$ ). ${ }^{7}$ The framework should complement contracts, putting in place mechanisms that would establish how to solve disputes fairly. Building it on a consensual basis will be essential for its success. This in turn requires fulfilling a set of principles on which the different parties involved would agree, an issue that we analyze in this chapter. 
While the importance of the absence of an adequate mechanism for SDR has long been noted (see also Stiglitz, 2006), five changes have helped to bring the issue to the fore and motivate the global movement for reform of existing arrangements. (I) Once again, many countries seem likely to face a problem of debt burdens beyond their ability to pay. (2) Court rulings in the United States and United Kingdom have highlighted the incoherence of the current system and made debt restructurings, at least in some jurisdictions, more difficult if not impossible. (3) The movement of debt from banks to capital markets has greatly increased the difficulties of debt renegotiations, with so many creditors with often conflicting interests at the table. (4) The development of credit default swaps (CDSs)--financial instruments for shifting risk-has meant that the economic interests of those at the bargaining table may actually be advanced if there is no resolution. (5) The growth of the vulture funds, whose business model entails holding out on settlement and using litigation to get for themselves payments that are greater than the original purchase price and of those that will be received by the creditors who agreed to debt restructuring, has also made debt restructurings under existing institutional arrangements much more difficult. ${ }^{8}$

The sections in the remainder of this chapter are organized around the following topics: the objectives of restructuring; the current problems; the solution proposed by the ICMA and the IMF; analysis of the limitations of the ICMA-IMF solution; a set of further reforms that could be implemented within the contractual approach; and the principles that should guide the creation of a multinational formal framework for SDR.

\section{THE OBJECTIVES OF RESTRUCTURING}

In absence of information asymmetries and contracting costs, risk-sharing (equity) contracts would be optimal; there would be no bankruptcy. But under imperfect information and costly state verification, complete risk sharing is suboptimal, and the optimal contract is a debt contract (Townsend, 1979). ${ }^{9}$

Information asymmetries and costly monitoring characterize the world of sovereign lending, which explains the widespread utilization of sovereign debt contracts. The optimal debt contract may be associated with partial risk sharing, including default in bad states and a compensation for default risk in the form of a higher (than the risk-free) interest rate in good states. 
If default were never possible, the borrower would absorb all the risk. Under the assumptions of risk-neutral lenders who can diversify their portfolios in a perfectly competitive environment, the expected utility of each lender (who is compensated for the opportunity cost) ${ }^{\mathrm{IO}}$ would be the same, but the borrower's would be lower than it would be with good risksharing contracts. Moreover, if the possibility of default were ruled out in every state of nature (for instance, through sufficiently high penalization of default), the amount of lending would be severely limited.

The probability of entering into situations of debt distress depends on a range of economic conditions ${ }^{\text {II }}$ but also on the actions of the debtor. ${ }^{\mathrm{I2}}$ And once the distress arises, the debtor's capacity for production and repayment going forward will depend on how the debt situation is resolved. If the debtor defaults, he or she normally loses access to credit markets until a restructuring agreement is reached. ${ }^{13}$

The mechanisms in place for debt restructuring determine how all these tensions are resolved. A good system should incentivize lenders and debtors to behave in ways that are conducive to efficiency ex ante (i.e., the "right" decisions at the moment of lending) and ex post (i.e., at the moment of resolving a debt crisis). It should also ensure a fair treatment of all the parties involved.

EFFICIENCY ISSUES

A system that makes restructurings too costly induces political leaders to postpone the reckoning. When there are no mechanisms in place that would ensure orderly restructurings, the perceived costs of default to the party in power become too large. Therefore, "gambling for resurrection," delaying the recognition of debt unsustainability, may be the optimal strategy for the debtor.

Delays are inefficient. They make recessions more persistent and decrease what is available for creditors if a default occurs. ${ }^{\mathrm{T}}{ }^{\mathrm{T}}$ In the presence of cross-border contagion, furthermore, the delay is costly not only to the given country but to those with which it has economic relations (Orszag and Stiglitz, 2002).

The objective of the restructuring process itself must not be to maximize the flows of capital or to minimize short-term interest rates. Instead, the framework should ensure overall economic efficiency, a critical feature of which is ex post efficiency in a broader sense: it should provide the conditions for a rapid and sustained economic recovery. A system of 
orderly discharge of debts would permit the debtor to make a more efficient use of its resources, which may be in the best interests of both the debtor and the creditors. Normally, contractual and judicial arrangements should support this kind of ex post efficiency that is necessary for achieving Pareto efficiency. ${ }^{\text {IS }}$

A curious feature of the current restructuring process is that countries that are in the process of restructuring typically face massive underutilization of their resources. This is because such countries cannot get access to external resources; financial markets often become very dysfunctional in the midst of a crisis, with adverse implications for both aggregate demand and supply. Creditors, focusing narrowly and shortsightedly on repayment, force a cutback in government expenditures (austerity), and the combination of financial constraints and decreases in private and public demand bring on a major recession or depression. They wrongly reason that if the country is spending less on itself, it has more to spend on others-to repay its debts. But they forget the large multipliers that prevail at such times: the cutbacks in expenditure decrease gross domestic product (GDP) and tax revenues. The underutilization of the country's resources makes it more difficult for it to fulfill its debt obligations--the austerity policies are normally counterproductive even from the creditors' perspective.

Another critical feature is ex ante efficiency. A system that does not put any burden on the lenders ex post does not provide the right incentives for due diligence ex ante. Selection of "good" borrowers requires, in general, specific actions from the lenders, such as screening (before lending) and monitoring (after lending). The existence of a mechanism for SDR would act as a signal that money will be lost unless due diligence is applied.

Note that good due diligence will result in better screening and lending practices, so interest rates may actually be lowered as a result of better bankruptcy laws (i.e., more punitive bankruptcy procedures may so adversely affect lender moral hazard that financial markets become more dysfunctional). This is especially the case when, as now, large fractions of lending are mediated through capital markets, not banks. Arguably, that was one of the consequences of the passage of the creditor-friendly U.S. bankruptcy law reforms in 2005 (through the Bankruptcy Abuse Prevention and Consumer Protection Act), which made the discharge of debt more difficult and led to a substantial increase in bad lending practices. 
The framework for restructuring determines the incentives for creditors' behavior. A system that favors holdout behavior creates a perverse moral hazard problem that makes restructurings more difficult, or, on occasion, impossible.

It also creates interdebtor inequities, as it increases the borrowing costs for those debtors more likely to need a restructuring (which is both an efficiency and an equity issue, as the lack of proper mechanisms affects all countries but those that are riskier more severely). Of course, debtors who are more likely to default should pay a higher interest rate. The problem is that if the restructuring mechanism is inefficient-as the current system is - it overpenalizes these borrowers, and the ex post inefficiency also gets translated into an ex ante inefficiency, as the unnecessarily high penalty discourages participation in the credit market.

A flawed system like the current one that relies more on mechanisms for "bailouts" (such as the European Stability Mechanism) instead of providing mechanisms for restructuring also creates large intercreditor inequities, as only the creditors that get paid with the resources of the "bailouts" benefit, while the expected value of the claims of the other claimants (such as the creditors whose debts mature in a longer term, or the workers and pensioners whose wages depend on a production capacity of an economy that decreases precisely as the consequence of the austerity often associated with those plans) decreases.

Finally, there is a problem of equity between formal and informal creditors - those who have a contract and those whose benefits are part of a social contract. This is one of the important ways in which sovereign debt is different from private debt. Typically, there are a large number of such claimants - pensioners or those depending on the government for health benefits or education. Though Chapter 9 of the U.S. Bankruptcy Code (pertaining to the bankruptcy of public bodies) recognizes the importance of these claimants, in the absence of an international rule of law that gives such claims formal recognition, their claims are at risk of being made subordinate to those of the formal creditors. And the recognition that this is so may itself have a distorting effect on the economy: it may encourage the formalization of such claims, even when such formalization may result in socially undesirable rigidities and undesirable institutional arrangements. 


\section{THE CURRENT PROBLEMS}

The current non-system does not achieve the described objectives of restructuring. Instead, it creates a host of inequities as well as inefficiencies. It overpenalizes debtors in distress, causing delays in the recognition of the problems. It leads to the "too little, too late" syndrome. In some cases, there is too much lending - and too much suffering later on; in other cases, there may be too little lending. Moreover, the legal frameworks permit a situation in which a few specialized agents (the vulture funds) can block the finalization of a restructuring, imposing large costs on the debtor and on other creditors. This section describes various factors that lead to these problems.

\section{THE VULTURE FUNDS}

Restructurings involve a public good problem: each claimant wants to enjoy the benefit of the country's increased ability to repay from debt reduction, but each wants to be repaid in full.

The existing frameworks fail to solve the public-good problem. Instead, they provide the conditions for the emergence of vulture funds. The vulture funds are a class of holdouts that are not really in the business of providing credit to countries. Instead, they are engaged in "legal arbitrage." Their business consists in buying debt in default (or about to be in default) in secondary markets at a fraction of its face value. Then, they litigate in courts, demanding full payment on the principal plus interest (typically at an interest rate that already includes compensation for default risk). A victory in court brings exorbitant returns on the initial investment.

Their modus operandi relies on a legal framework that has weakened sovereign immunity and on a flawed design of contracts. They resort to activities (many of which are socially unproductive) to increase their bargaining power and to influence the decisions of the actors involved-including lobbying and threats about economic and political consequences of a failure to reach a settlement satisfactory to the creditors (some liken it to extortion) to affect the debtor's behavior. Economic "extortion" is especially effective in influencing countries needing to re-enter capital markets, and political extortion is especially effective in influencing governments whose officials have been engaged in illegal activities or who are motivated by a concern over their "standing" in the international community. 
The presence of vulture funds creates huge inefficiencies and inequities in sovereign lending markets. It can even lead to the total impossibility of debt restructuring. Recent events-in particular, the Argentine debt restructuring, which pitted the country against NML Capital (a subsidiary of the hedge fund Elliott Management) — show that these inefficiencies are a major issue. In that case, the presiding U.S. federal judge, Thomas Griesa, ruled in favor of the vulture funds and ordered an injunction that obliged Argentina to make payments to vultures and the holders of bonds denominated in foreign currency issued by Argentina in the 2005 and $20 r 0$ debt exchanges on a ratable basis, an interpretation of pari passu that requires Argentina to pay to the vulture funds their full judgment whenever it makes any payment under the exchange bonds, even if it is just a coupon payment, or otherwise any holder of exchange bonds would be barred from receiving payments. The injunction was based on a peculiar interpretation of pari passu, ${ }^{16}$ a contractual clause that is supposed to ensure equal treatment among equally ranked creditors. ${ }^{17}$

The design of contracts also facilitates the emergence of vulture funds. Many existing debt contracts do not have CACs-clauses that allow a majority of bondholders to agree to changes in bond terms (e.g., to reduce the value of the principal) that are legally binding to all the bondholders, including those who vote against the restructuring. Some contracts do include them, but most are defined at the level of each individual bond. ${ }^{18}$

Under a unanimity rule, vulture funds can easily emerge. With CACs at the level of each security, vultures' behavior is more constrained but is still possible. They can still buy the minimum fraction that would block the restructuring of a unique series of bonds, and by doing so they would be able to block the whole restructuring.

A formula for aggregation of CACs (over different classes of bonds), like the one proposed by ICMA discussed later in this chapter, would alleviate these problems. But it raises other questions: How are different bonds to be added together for purposes of voting (How do we adjust for differences in priorities and exchange rates)? It is clearly conceivable that a majority of junior bonds could vote to deprive more senior bonds of some of the returns they might have expected, given their seniority. There may even be ambiguity about which claimants should be included in the aggregation: Should foreign and domestic claimants be included? ${ }^{19}$

Clearly, the issues faced in SDRs go beyond the design of CACs. These clauses are no panacea. If they were, there would be no need for bankruptcy laws that spell out issues like precedence and fair treatment. 
Evidence shows that no country has relied on markets to solve bankruptcies. Every country has a bankruptcy law. Theory also shows that under realistic conditions markets are not able to provide efficient restructurings on their own, as they are unable to reach efficient solutions on their own in general, except under very restrictive and unlikely conditions (Greenwald and Stiglitz, I986). ${ }^{20}$ There are important market failures that are present in restructurings--either for corporations or for sovereigns.

WEAKENING OF SOVEREIGN IMMUNITY

AND THE CHAMPERTY DEFENSE

The evolution of the legal frameworks has been instrumental for the emergence of vultures and the debilitation of sovereign immunity. Sovereign immunity had first been challenged with the sanction of the Foreign Sovereign Immunity Act in 1976 (Schumacher, Trebesch, and Enderlein, 2014), and has more recently been challenged by litigation over the champerty defense-an English common-law doctrine, later adopted by U.S. state legislatures, that prohibited the purchase of debt with the intent of bringing a lawsuit against the debtor (Blackman and Mukhi, 20I0).

The case Elliott Associates, LP v. Republic of Peru was a game changer for the interpretation of legal frameworks affecting sovereign immunity. ${ }^{2}$ Elliott had bought Peruvian debt in default and sued the country for full payment in the New York courts. The U.S. District Court for the Southern District of New York ruled that champerty applied, dismissing Elliott's claims. But the Second Circuit of Appeals reversed the decision, stating that the plaintiff's intent in purchasing the Peruvian debt in default was to be paid in full or otherwise to sue. Then, according to the Second Circuit, Elliott's intent did not meet the champerty requirement because litigation was contingent. Such an interpretation is absurd, as it was not reasonable to expect to be paid in full over a promise that had already been broken. The exorbitant returns obtained based on an interpretation that was unreasonable to expect could have constituted a case of "unjust enrichment" (Guzman and Stiglitz, 2014c).

In 2004, the New York state legislature effectively eliminated the defense of champerty concerning any debt purchase above US\$500,000 dollats. That decision constituted a change to the understanding over which hundreds of billions of dollars of debt had been issued, redefining property rights. This change in legislation ensured the good health of the vultures' business. 
The problems are aggravated by the nontransparent use of CDSs. A CDS separates ownership from economic consequences: the seeming owner of a bond could even be better off in the event of a default, as the payments over the CDS would be activated in such an event. The opacity of this market makes unclear the real economic interests of those who have a seat at the restructuring bargaining table. They provide another reason for delayed restructuring, with its associated inequities and inefficiencies.

THE UNBALANCED BACKGROUND FOR NEGOTIATIONS

The legal frameworks and the bailout policies of the IMF determine the background of the negotiations (cf. Brooks et al., 2015). The current arrangements favor short-term creditors against long-term creditors; included in the latter group are the "informal creditors" (citizens toward whom the sovereign has obligations, such as workers and pensioners).

IMF bailout policies only aim at ensuring repayment in the short run. In practice, they have not been designed with the purpose of favoring sustained economic recoveries. On occasion they even undermined them (both as a result of counterproductive conditionality and because of insufficiently deep restructuring), increasing the probability of a subsequent restructuring being needed down the road.

In the case of Europe, the European Stability Mechanism leads to the same perverse effects. By construction, it is not a mechanism for debt restructuring but a mechanism for bailouts that gives creditor countries enormous power in the negotiations with a debtor country (Brooks and Lombardi, 2015). In the case of Greece, it was the main instrument by which the eurozone countries enforced their demands for policy decisions that were not in the best interest of the country (at least as judged by the vast majority of people in the country, as reflected repeatedly in the polls, and by a large fraction of economists).

\section{POLITICAL ECONOMY ISSUES}

SDR mechanisms must take political economy issues into account. The costs of restructuring are usually borne by different political actors than those who created the problem. Political economy 
tensions increase in times of distress, when the incumbent government has larger incentives to achieve deals with short-term benefits but long-term costs that will be paid by the next government. One of the strategies for better short-term financing conditions is giving up on sovereign immunity.

Every bad loan is equally the result of bad lending and bad borrowing: these are voluntary agreements. But a system the puts the onus on the debtor (i.e., making it more likely that more of the debt will be repaid) encourages bad lending - it encourages banks to encourage the government today to borrow too much, exacerbating the already present distortion. (There is a further argument for putting more of the onus on the lenders: they are supposed to be the experts in risk analysis; that is supposed to be their comparative advantage. Government officials typically have no expertise and rely on the judgments of those in the financial market concerning reasonable debt levels.)

Political costs are also often borne disproportionately by those willing to take actions - - that is, to actually do the restructuring. Thus, a system that makes restructurings too costly exacerbates these natural political economy tensions, because it incentivizes debtors to delay the recognition of problems.

Creditors' behavior may also worsen these distortions, for instance, by providing short-term lending at high interest rates to countries that are obviously in need of a restructuring, taking into account the distorted incentives of the distressed debtors to make use of those funds, the "gambling on resurrection" behavior that we described earlier. Such short-term lending is, of course, risky: when the situation is bad enough, eventually there will be a restructuring. But the short-term creditors can typically charge a sufficiently high interest rate to compensate them for this risk.

There are also political economy problems on the creditors' side. Sovereign bonds are an important form of collateral. A decrease in the value of bonds held by banks would decrease the value of collateral, affecting lending and (reported) profits. But when bonds (loans) are not marked to market, ${ }^{22}$ what matters is the recognition of the loss. A debt write-off forces the recognition of the loss. ${ }^{23}$ Thus, banks have incentives to resist debt write-offs. The incentives turn more perverse when the managers' relevant horizon is short-as is typically the case, especially when, with bad corporate governance; compensation is linked to shortterm performance metrics. 
The ICMA, with the support of the IMF, proposes to resolve the failures in SDR by modifying the debt contracts' language. The new terms include a formula for aggregation of CACs and a clarification of the pari passu clause. ${ }^{24}$

The formula for aggregation allows bondholders across different series of bonds to vote collectively in response to a restructuring proposal. The decisions of a supermajority (defined by acceptance of the aggregate principal amount ${ }^{25}$ of outstanding debt securities of all of the affected series) would be binding to all the bondholders across all series.

The clarification of pari passu establishes that, unlike Judge Griesa's interpretation in Argentina's case, "the Issuer shall have no obligation to effect equal or ratable payment(s) at any time" with respect to any other external indebtedness of the issuer, and in particular the issuer "shall have no obligation to pay other External Indebtedness at the same time or as a condition of paying sums due on the Notes and vice versa" (ICMA, 20I4, I). In other words, ICMA states that pari passu does not mean what Judge Griesa interpreted it to mean.

These new terms are improvements over the previous ones but leave some important issues unaddressed. We analyze these issues in the next section.

LIMITATIONS OF THE PRIVATE CONTRACTUAL APPROACH:

WHY A MARKET-BASED APPROACH WILL NOT SUFFICE

SDRs are more complex than private debt restructurings. They involve dealing with contracts issued under different terms, under different legislation from different jurisdictions, and different currencies, over which there may not be obvious ways for comparing values when the contracts need to be rewritten. At those times, distributive conflicts get magnified. ${ }^{26}$ The private contractual approach does not solve these issues according to efficiency or equity considerations but on the basis of relative bargaining strength (related, for instance, to the ability to withstand large litigation costs and delays). Outcomes are generally inefficient and inequitable. That is why no government relies on the private contractual approach within its boundaries for private debts. The advocates of the private contractual approach have never explained why, if it were as good as they claim, it has been universally rejected. And as the complexities of SDR are greater, the need for a statutory approach is larger. 
The IMF estimates that roughly 30 percent of the $\$ 900$ billion in outstanding bonds issued under the old terms will mature in more than ten years. Approximately 20 percent of those stocks do not include any kind of CACs, and virtually all of the 80 percent that does include them have CACs that operate only at the level of each security (IMF, 20I4). What would prevent the current problems from arising if those debts had to be restructured (events which, unfortunately, are especially likely to occur in the context of an anemic global economy)?

Debt issued under the old terms could in principle be exchanged for securities that incorporate the new terms. But what would rule out holdout behavior if such a proposal were carried out? The vultures would have an incentive not to exchange existing bonds for these new bonds. There is no solution to this quandary within the improved contractual approach.

INTERCREDITOR FAIRNESS

There are complicated bargaining problems among classes of creditors. A supermajority voting does not solve them all.

A simple supermajority rule could lead to a situation wherein junior creditors vote to have themselves treated equally with more senior creditors and can impose their position through a supermajority. ${ }^{27}$ This would make the senior status conditional on the outcome of the bargaining process. Indeed, if senior creditors were sufficiently small relative to the junior creditors, there is a presumption that their seniority would not be fully taken into account, and under the proposed arrangements, there is nothing they could do about it. Senior creditors would anticipate this possibility and would react by demanding different contract terms ex ante (for instance, an early senior creditor might limit the amount of junior creditor bonds that could be issued so as not to dilute voting interests, but that would have a deleterious effect on growth; alternatively, he or she could demand a higher interest rate ${ }^{28}$ ).

When countries issue debt under different jurisdictions, establishing priority of claims could be a daunting task, with multiple contradictions. Contracts could become inconsistent in crisis times. For example, the terms of a bond issued under the jurisdiction A could state that the holder of that bond has priority over all the other claims. But at the same time another bond issued under the jurisdiction $\mathrm{B}$ could state the same. If it were not 
possible to satisfy both claims at the same time, how would priority be determined? Who would ultimately judge over it? It might be impossible to ensure the consistency of rulings from judges of different jurisdictions. ${ }^{29}$

The same bargaining problems may arise when a default is accompanied by a currency crisis, and the country issues debt under multiple currencies. How should debts that mature in the future be valued in the present in the event of a default? What nominal exchange rate should be used? The holders of debt denominated in a currency that is rapidly depreciating would claim that they should be weighed for purposes both of settlement and voting on the basis of a "normal" (i.e., strong) exchange rate, while the holders of debt denominated in the other currencies would argue the opposite, as each party attempts to maximize what he or she receives. It would be unfair to effectively deprive domestic bondholders of their voting rights in the event of a temporary curtency crisis; and if that happened, opportunistic bondholders in foreign denominated bonds would have an incentive to seize the opportunity to effectively discriminate against the domestic bondholders.

Finally, how should the informal claimants (such as workers and pensioners) be treated? Under CACs, they would have no voting rights. A solution to this problem within the contractual approach is not easy. Governments could decide to give full creditor rights to social security claimants. But then government agencies would be fiduciary for those claimants, which might "drown out" traditional creditors--an issue that would be anticipated and that would also be reflected in the interest rates and the contract terms.

Under a decentralized private contractual approach, anticipating all of these possibilities would result in highly complex contracts, and solving the disputes would require intricate and lengthy negotiations, with complex legal questions, and would almost surely cast a pall of uncertainty over what might happen in the event of the need for a restructuring.

\section{SIGNALING EQUILIBRIUM}

In the presence of imperfect information, debtors try to show that they are of a "good type" by using costly signals.

In the context of sovereign debt, debtors may choose excessively "tough" jurisdictions to signal they are unlikely to default-jurisdictions that will make an eventual restructuring very difficult. Other debtors, by acting differently, would signal that they are more likely to restructure. 
Hence, the net payoff of deviating to a more reasonable jurisdiction would be negative. The result is an inefficient global equilibrium..$^{30}$

Besides, bargaining models with imperfect information often result in excessive delay - delay itself is a costly signal-again leading to an inefficient global equilibrium.

POLITICALECONOMY ISSUES

As described earlier, sovereign lending markets are featured by important political economy tensions both on the debtor and the creditor side. A purely market-based approach for debt crisis resolution would only exacerbate these tensions, leading to inefficient solutions.

On the debtor side, a free-market solution will not internalize the negative externalities of an incumbent government willing to take actions that result in short-run benefits (like giving up on sovereign immunity to receive better financing conditions), leaving succeeding governments to pay the costs. The frameworks for SDR should recognize these perverse incentives and should consequently make it impossible to sign away sovereign immunity.

On the creditor side, a decentralized negotiation would face the opposition of investors who use sovereign bonds as collateral and, in a world of less than perfect corporate governance, will oppose the devaluation of the bonds in the short term, even if not writing debt off leads to more sustainability problems and larger haircuts in a longer term.

\section{POSSIBLE FURTHER IMPROVEMENTS TO} THE CONTRACTUAL APPROACH

There are other modifications to the standard contract that could improve the workings of the market-based approach. They entail regulations on contracts, changes in domestic legislation, and the inclusion of clauses that make debt payments contingent on the economic situation of the debtor.

REGULATION OF SOVEREIGN CREDIT DEFAULT SWAPS (SCDSS)

CDSs have been advertised as helping to complete markets. ${ }^{3 \mathrm{I}}$ But they have failed to do so and instead have made matters worse. The use of SCDSs distorts incentives. 
SCDSs distort incentives when they are used for insurance purposes (as noted earlier). But third parties can also demand SCDSs for speculation purposes. This would not necessarily be a problem if there were no connections between the actions of the buyers and the interests of the sovereign. But the lack of transparency of these markets makes the connections possible (and profitable)..$^{32}$

To avoid conflicts of interest that could undermine the success of restructurings, and considering that the opacity of CDSs markets makes regulation too difficult, all CDS positions of parties involved in the restructuring negotiations should be fully disclosed. ${ }^{33}$

REINSTATING VARIANTS OF THE CHAMPERTY DEFENSE

If investors who purchase debt in default were willing to settle under "reasonable" conditions, they would just provide a liquidity service in the markets for defaulted debt and could thus contribute to avoiding an even larger depression in bond prices in such circumstances. But that is not what vulture funds do. Reinstating variants of the champerty defense that prohibit the purchase of defaulted debt with the intent of litigating against the issuer, together with a clarification of the pari passu clause, would undermine the vultures' business, correcting the many inefficiencies associated with their behavior that we have identified. ${ }^{34}$

\section{GDP-INDEXED BONDS}

With GDP-indexed bonds, the principal is indexed to the nominal GDP of the country. The contingent element in the contract improves debt sustainability, as it makes debt obligations less butdensome when debt repayment is more difficult and vice versa. Creditors also benefit from a lower probability of default.

These securities may also be an effective part of SDR. Exchanging fixed-coupon bonds with GDP-indexed bonds would be akin to a debt-equity swap. The inclusion of this contingency clause would align the incentives of the debtor and the creditors, as each would benefit from the faster growth of the country. (Similar benefits might be achieved through the issuance of ordinary bonds, which automatically convert to GDP-linked bonds in the extreme events associated with crises.) 
The capacity for countercyclical fiscal policies would also improve. The numbers may be significant: Bank of England economists (Barr, Bush, and Pienkowski, 20I4) estimate that GDP-linked bonds can increase fiscal space, that is, they can increase the level of what is called "sustainable debt." 35 (It must be noted, however, that "debt limit" is a subjective concept whose quantification requires taking a stance on the expectations about the government's capacity for generating revenues-a complicated issue over which it is relatively easy to make wrong assumptions, especially in the most volatile economies, which are the ones more likely to need restructurings. The IMF itself has been systematically overestimating the speed of recovery of economies in crises and the multipliers in response to the conditionalities imposed on the bailed-out countries. See Guzman, 2014).

Even if these proposals were incorporated, the contractual approach would be insufficient. The approach needs to be complemented by a multinational legal framework-the object of analysis of the next section.

\section{A MULTINATIONAL LEGALFRAMEWORK FOR SDR}

A majority of countries have become convinced both by experience and the force of the arguments of the previous sections that the private contractual approach, no matter how improved, will not solve the basic problem of SDR. These countries are advocating for institutionalizing a multinational statutory solution, as reflected in Resolution 68/304, passed by the General Assembly of the United Nations on September 9, 2014.

\section{GUIDELINES FOR THE FRAMEWORK}

The framework must recognize the limitations of the private contractual approach. It needs to solve the "too little, too late" syndrome and the possibility that restructuring would take too long. It also needs to ensure a reasonably fair treatment of all parties.

Any framework for SDR must take account of the primacy of the functions of the state, its obligations to its citizens, and the "social contract" the state has with its citizens (Stiglitz et al., 20I5).

Although there are differences between sovereign debt and corporate debt restructurings, there are also important analogies. Thus, some of the provisions of Chapters 9 and II of the U.S. Bankruptcy Code should be considered (Stiglitz, 2002a, 20IOa). ${ }^{36}$ 
The sovereign should initiate the restructuring in a timely way. The framework should provide the right incentives for avoiding delays in the initiation and in the finalization of the restructuring. Therefore, it must set specific deadlines for the different stages of the process. This would make the whole process more predictable.

\section{LENDING INTO ARREARS}

The framework must recognize the macroeconomic externalities associated with debt crisis resolution. Thus, it should facilitate countercyclical macroeconomic policies. Provisions of lending into arrears, according to which creditors who lend while the restructuring process is being carried on would receive senior treatment, should be contemplated.

\section{STAYS}

Litigation induces costly delays. As previously described, it also creates a moral hazard problem, as it negatively affects creditors' incentives to enter into restructurings. Therefore, the framework should incorporate clauses of stays for litigation, which would prohibit litigation in courts between the initiation and the finalization of the restructuring process.

Litigations could still occur in jurisdictions that do not endorse the framework, remaining a problem, as a large proportion of debts will still be issued under those jurisdictions. However, judges of nonparticipating jurisdictions could consider the multinational framework as a reference on what good practice in SDR looks like.

\section{HARD LAW VERSUS SOFT LAW}

The design of the framework must consider what constitutes the set of principles on which all the parties involved would agree. One possibility could be to follow a "hard law" approach, in which countries adhere to an international bankruptcy court. If the rulings of the court were enforceable, countries would be giving up on sovereign immunity. Of course, any international treaty entails giving up on sovereignty and compromising sovereign immunity. The benefit would be a more orderly restructuring. But countries would, at least initially, worry about the fairness 
of the tribunal. Besides, geopolitical problems would be intense: How would the members of the international court be appointed? What interests would they represent? Indeed, it might even be difficult, at least initially, to define the principles that should guide restructuring. The intense debates within countries over the design of bankruptcy law should make it clear that resolving these issues internationally might be difficult. The creditor countries would push for creditor-friendly principles, with the debtor countries advocating for the converse.

There is a single principle countries could agree to that would restore a semblance of order to the global sovereign debt market: the restoration of sovereign immunity. More precisely: there is a consensus that there should be restrictions on what counts as acceptable contracts. Individuals cannot sell themselves into slavery. Many countries do not allow certain kinds of perpetuities. There should be a global agreement that no country can surrender its sovereign immunity (even voluntarily). Such a restriction is particularly important given the political economy problems discussed earlier. It is too easy for a government today to surrender the sovereign immunity of some government in the future, in return for money that would enhance its popularity and the wealth of its supporters.

To this should be added a framework that would facilitate restructuring. This would occur through what might be called a "soft law" approach, with the creation of an oversight commission with the mission of mediating and supervising the restructuring process. The commission would also maintain a registry of the debt stocks. The members of the commission would be countries that endorse the multinational framework. The commission would not rule over different alternatives. Instead, the sovereign would finalize the process with a final proposal and the commission would produce statements about the reasonability of the process and the final proposal. This approach would serve to legitimate the restructuring or, alternatively, to legitimate positions that speak of illegitimate restructurings. ${ }^{37}$

\section{CONCLUSIONS}

Restructuring is not a zero-sum game. The mechanisms in place can have large effects on the overall economic performance of the countries involved. The existing institutional arrangements make the sum too negative, as they delay the initiation of restructurings and lead to 
"solutions" that do not promote economic recovery--making recessions mote severe and persistent overall. Deficiencies in the restructuring process also get reflected ex ante in the terms and volumes transacted in sovereign debt markets.

The world of debt restructuring needs to move to a different equilibrium. There is consensus on the necessity of this, but there are different views on how to move forward. ${ }^{8}$ On the one hand, the business community and the IMF advocate for tweaking the terms of contracts. Although the suggested new terms (aggregation of CACs and clarification of the pari passu clause) are improvements over the old terms (terms that clearly did not work), they still leave a legacy of problems unaddressed. There are further improvements that can be implemented, as we discussed earlier.

But with incomplete contracts, even with all those improvements, a variety of problems will remain. In times of default, debt contracts will need to be rewritten. Under a market-based approach for restructurings, outcomes will be more determined by bargaining power than by considerations of efficiency and equity. Particularly disturbing is the fact that most countries that are entering debt restructurings are in particularly weak positions and are therefore particularly vulnerable to pressure from creditors to agree to terms that are adverse to their long-term interests. And the knowledge that this is so gives rise itself to bad lending practices, especially in the context of the political economy problems we discussed earlier: creditors encourage more lending than is socially efficient, in the knowledge that they can use their market power to extract a favorable outcome for themselves in the event of a crisis. At least in the past, practices of the IMF, which provided funds to the government to bail out the creditors-ensuring that they were paid in full-only exacerbated the problem. ${ }^{39}$

A comprehensive solution requires the implementation of a statutory approach at the multinational level — an approach that helps "complete" contracts. The framework needs to address the limitations of the current approach. It needs to redefine the balance among the parties involved in the negotiation. It should be built respecting the principles on which the different actors involved would agree.

For now, the single most important change over which there is the possibility of getting agreement is the restoration of sovereign immunity and the recognition that no government can sign away sovereign immunity for itself or for successor governments. 
We believe a soft law approach that entails a more active role for a quasi judiciary can mitigate some, perhaps many, of the inefficiencies and inequities noted earlier. While this approach is not a panacea, we believe it represents a substantial step forward-and a substantial step beyond the private contractual approach.

\section{N O TES}

We are indebted to Sebastian Ceria, Richard Conn, Juan José Cruces, Anna Gelpern, Matthias Goldman, Barry Herman, Daniel Heymann, Brett House, Charles Mooney, Kunibert Raffer, Wouter Schmit Jongbloed, and Sebastian Soler; the participants of the Conference on "Frameworks for Sovereign Debt Restructuring" at Columbia University, the ECON 2014 Forum at University of Buenos Aires, the RIDGE Forum on Financial Crises at Central Bank of Uruguay, and the First Session of the Ad Hoc Committee of the United Nations General Assembly on a Multilateral Legal Framework for Sovereign Debt Restructuring; the seminar participants at Javeriana University (Bogota), the Central Bank of Argentina, the UNCTAD Conference on "Legal Framework for Debt Restructuring Processes: Options and Elements" at Columbia University, the INET Annual Conference at OECD, the Research Consortium for Systemic Risk Meeting at MIT, and the International Institute of Social Studies in The Hague; the Academia Nacional de Ciencias Económicas (Argentina), the CIGI-IPD Conference on Sovereign Debt Restructuring at Columbia University, the Central Bank of Colombia, FLACSO (Argentina), the RIDGE workshop on International Macroeconomics (Montevideo, 20Is), the RIDGE workshop on Sovereign Debt at University of Buenos Aires, and three anonymous reviewers for useful comments, discussions, and suggestions. We are grateful to the Ford and MacArthur foundations for support to the Roosevelt-IPD Inequality Project; the Institute for New Economic Thinking for financial support; and Debarati Ghosh and Ines Lee for research assistance. A previous version of this chapter was circulated with the title "Fixing Sovereign Debt Restructuring."

I. It is not high debt per se that is bad for economic growth or full employment, as careless studies that were influential in the policy debate have suggested (Reinhart and Rogoff, 20IO; see, in particular, the important critique of Herndon, Ash, and Pollin, 20I4). Indeed, standard general equilibrium theory argues that there is a fullemployment equilibrium regardless of the level of debt (Stiglitz, 20r4). Instead, it is the difficulty of running expansionary macro policies when primary surpluses are allocated to debt payments in times of recessions (which are indeed often associated with high debt) that makes debt a constraint for economic recovery.

Note, too, that even then it is not only the economic constraints that matter, but those arising out of political economy-a political economy which itself is affected by the largely ideological research referred to in the previous paragraph. 
In particular, for countries like the United States, which can borrow even now at a negative real interest rate-and borrowed at very low real interest rates even when its debt to GDP ratio was in excess of 130 percent-borrowing for public investments that yield significantly higher teturns than the cost of capital can improve the nation's balance sheet.

2. The only situation in which the temporary assistance (bailout) might make sense is if there is a liquidity crisis, e.g., markets are irrationally pessimistic about the country's prospects, with the evidence that they are wrong expected to be revealed in the not too distant future. But it is ironic that those in the financial market who normally profess such faith in markets suddenly abandon that faith when markets turn skeptical on them; and that at that point, they seem willing to rely on the judgment of a government bureaucrat or an international civil servant over that of the market. There are other irrationalities implicit in these arguments: it is sometimes suggested that if the intervention stabilizes, say, the exchange rate, that will restore confidence and prevent contagion. But if it is known that the reason that the exchange rate has been stabilized is that there has been IMF intervention, why should the stabilization of the exchange rate change beliefs, and especially so if the intervention is announced to be short term? And if there are reasons to believe that the IMF would not intervene in other countries (e.g., because they are less systematically important or less politically connected), then why should the intervention in one country change beliefs about the equilibrium exchange rate in the others? It is even possible that it could have adverse effects (Stiglitz, 1998).

3. Even if the funds were offered without such conditions, to the extent that the funds are not used for addressing the fundamental problems that make debts unsustainable, the country would be worse off over the long run, unless there was commitment to provide these funds indefinitely - which is in effect equivalent to a debt write-off.

4. Since bonds replaced loans, nearly 40 percent of restructurings ended in redefault or another restructuring within five years (Gelpern, 2015).

5. And when they do not take too long, they may not achieve the objectives of restructuring that we define in the section on the objectives of restructuring. This is the case of the Greek debt restructuring in 2012. The deal was mostly a socialization of banks' debts that was not conducive to the recovery of the economy. Three years later, the country is still suffering, with an more deeply depressed economy: GDP has fallen by 25 percent since the beginning of the recession, and the unemployment rate was above 25 percent in January 2015 (as reported by the Hellenic Statistical Authority Labor Force Survey, 2015).

6. Where an American court seemingly has taken an action affecting payments on Argentinean bonds issued in other jurisdictions, such as the United Kingdom, and a British court has ruled that they cannot do so (England and Wales High Court (Chancery Division) Decisions, Case No.: HC-2014-000704).

7. This is not the first attempt to implement a framework of this nature. The IMF had called for the implementation of a sovereign debt restructuring mechanism (Krueger, 20or; although the IMF executive board would have determined sustainability and judged on the adequacy of the debtor's economic policies, a task in which it has not excelled in recent times (see Guzman and Heymann, 2.015)), and the report of 
the International Commission of Experts of the International Monetary and Financial System appointed by the president of the General Assembly of the United Nations had pointed out the necessity of exploring enhanced approaches for the restructuring of sovereign debt (Stiglitz et al., 2010).

8. We will explain some of the reasons for the growth of vulture funds later in the chapter.

9. In private debt markets, other considerations relating to adverse selection and moral hazard also militate for at least some reliance on debt. See, e.g., Stiglitz (1985). The problems of costly state enforcement for sovereign debt markets have, we think, been greatly exaggerated, and there have been several important proposals for such bonds. (Argentina actually introduced GDP-linked bonds as part of its debt restructuring.)

ro. This would be true even if lenders were risk averse and markets highly competitive. Under these assumptions, each lender would receive the certainty equivalent return from each of his or her investments. Though such an assumption dominates within the finance literature, there are reasons to be skeptical. Still, the conclusion holds that forcing the borrower to absorb all the risk is not efficient.

II. Importantly, it also depends on the discrepancy between the expectations on the future capacity of repayment and the realizations that determine the actual capacity of repayment. See Guzman (2014).

I2. The nature of the distress also depends on actions of the creditors, i.e., their willingness to roll over.

I3. There is some controversy over whether there is a stigma that makes it more difficult for the borrower to borrow after the resolution of the debt. There is theory (and some evidence) that markets are forward looking, infer that the cost of bankruptcy is sufficiently high that few if any countries go into default if they can avoid it - and that therefore there is no inference of a flawed "character trait" that can be made from a default; as a result of the cleaning of balance sheets, at least following a deep restructuring, there will be more access to credit markets. Russia's I998 default falls into this model. See Stiglitz (2orob)

I4. That is, there are both macro-inefficiencies and micro-inefficiencies. In the chaos surrounding disorderly debt distress situations, assets typically do not get used in the most efficient way, and complementary investments to those assets are not undertaken.

I5. It is important to realize that the normal presumption that markets on their own are efficient fails in this context for a large number of reasons: there are imperfections and asymmetries and incomplete risk markets (and in such situations, there is a strong presumption that markets are not efficient). Moreover, the context with which we are most concerned-in which there is significant underutilization of resources-is again one in which there is a presumption of market inefficiency. Finally, the bargaining that surrounds debt resolution is itself evidence of the absence of perfect competition, another essential assumption if markets are to be efficient. See, e.g., Greenwald and Stiglitz (1986)

I6. The judge's decision was peculiar in other ways: it forced the trust bank into which funds were deposited to enforce his decision, i.e., the trustee was forbidden from distributing funds that it had received on behalf of the restructured bonds. Thus, 
to enforce one contract, it had to break other contractual arrangements. There seemed to be little rationale for the court's decision about which contracts to respect and which to abrogate. Thus, the decision was not (as it has sometimes been put) about the sanctity of contracts (see chap. 4 by Sergio Chodos in this volume).

I7. The upshot is that vulture funds are poised to get returns on their "investments" more than five times greater than the holders of the exchange bonds.

I8. In the 1990s, bonds issued in the London market under the English law contained CACs, while bonds issued in the New York market under the law of the state of New York did not (Eichengreen and Mody, 2003). Mexico was the first country to put these clauses in its contracts under the jurisdiction of the state of New York in 2003.

I9. In a world of globalization, the distinction between foreign and domestic bonds may not be clear. Moreover, the rules of the game would be expected to change the mix.

20. This is especially true when there are large macro-economic disturbances. See Miller and Stiglitz (1999, 2010).

2I. See Elliott Assocs. v. Republic of Peru, 96I F. Supp. 82, 86-87 (S.D.N.Y. 1997), and $x_{94}$ F.3d 363 (2d Cir. 1998 ).

22. Even with marked to market, there is always a chance that the country will recover and the bonds will pay off. If the write-down is greater than the expected loss (recall that if there is not a restructuring now, there is a chance, even a likelihood, that matters will get even worse, and the necessary write-down will be even greater), then the write-down will be associated with a decrease today in the value of the firm.

23. Similar problems arise, of course, with domestic debt, and played an important role in the evolution of the U.S. financial crisis. See Stiglitz (zorob)

24. See Gelpern, Heller, and Setser (2016) for a description of the ICMA's proposal.

25 . There is still a problem when debt is issued in different currencies and there are marked changes in exchange rates (as in the East Asian crisis). Depending on the rules, it may be relatively easy for a vulture fund to buy enough bonds to block a restructuring or to obtain a settlement that advantages it over other claimants (the issue is more extensively analyzed in the section analyzing the limitations of the ICMA-IMF solution). Similar problems can arise when there are different maturities: long-dated bonds might, for instance, sell at a marked discount relative to principal values.

26. That is, if the country had issued only one set of bonds, there would be a clear meaning to equity: repayments should be proportional to the face value of the bonds. This is not so if, as is the case in practice, there are many different kinds of bonds.

27. In the world of sovereign bonds, bondholders are on an equal foot. However, some creditors (the IMF for instance) are de facto treated as senior creditors. But nothing prevents the possibility that in the future there could be unsubordinated debt not only de facto to official creditors but also de jure to other bondholders. Indeed, the legal literature suggests that this is feasible (cf. Chatterjee and Eyigungor (2015) for a concrete proposal). A comprehensive solution must also address this concerns (Mooney, 2015).

28. Moreover, the set of contracts in the market will respond endogenously to the rules of the game. For instance, the senior debt contract could have a provision that in the event of a default, the face value of what is owed is multiplied such that, under the aggregation clause, those bondholders have sufficient votes to block any proposal by junior creditors. 
29. See Guzman and Stiglitz (2015b) for a description of the interplay between legal jurisdictions in the case of Argentina's restructuring after the 200 r crisis.

30. This is a standard result in the theory of adverse selection and signaling.

3I. Arrow and Debreu have established that only if there were a complete set of risk markets would competitive markets be efficient. Some in the financial market therefore argued that introducing new securities (such as CDSs) helps complete the marke and thus improves societal welfare. But that conclusion ignores the basic insights of the theory of the second best, which demonstrates that in the presence of multiple market failures, reducing the scope of one could actually (and under plausible conditions often would) lead to a decrease in societal welfare. Thus, Newbery and Stiglitz (I982) showed that eliminating barriers to trade, in the presence of imperfections in risk markets, could lead all individuals in all countries to be worse off.

In this context, Guzman and Stiglitz (20I4a, 20I5a, 20I5d) have shown that introducing these new instruments for betting may actually increase economic volatility and lower output permanently.

32. The recent case of Argentine debt restructuring illustrates how perverse incentives can turn. In the aftermath of Judge Griesa's injunction that blocked the payments of the country to its bondholders, the International Swaps and Derivatives Association (ISDA) classified the credit event as a default. Interestingly, one of the members of ISDA committee was Elliott Management, the same vulture fund that was litigating against the country. (The debt contract only specified that Argentina turn over the requisite funds to the "agent"--which Argentina did. Argentina was thus not in breach of the contracts it had signed in the process of restructuring. Indeed, Argentina had even warned investors in its contract of the possibility of these difficulties. That is why the so-called default has been labeled a Griesafault, to distinguish it from a norma default, wherein a party actually breaches a key contract provision. See Guzman and Stiglitz [2014b]).

33. Some have suggested going further: banning the purchase of SCDSs by third parties (Brooks, Guzman, Lombardi, and Stiglitz, 2015).

34. One could even imagine some variant of such a clause being inserted into the contract: that no secondary purchasers of the bond could make a claim in court for an amount greater than the price at which he or she had purchased the bond. While such a provision arguably might lower the price of the bond at issuance (requiring the sovereign borrower to pay a higher interest rate), the effect is likely to be minimal: few buy a bond on the expectation that it will go into default.

35. When debt becomes too high, then, depending on the rate of growth of the economy and the rate of interest, the ratio of debt to GDP increases without bound. Barr, Bush, and Pienkowski (20I4) argue that switching to GDP-linked bonds increases the critical threshold by some 45 percent.

36. Raffer (1990, 20I5) explains that the essential points of the special insolvency procedure for municipalities in the United States (Chapter 9, Title II, U.S.C.) can be easily applied to sovereigns.

37. For an analysis of the international-law elements on which a multinational formal framework could be drawn, see Howse (2016).

38. The different chapters in this volume reflect both the consensus and the differences in views on how to move forward. See, for example, Conn (2016) 
Herman (2016), Howse (2016), Kaiser (2016), Ocampo (2016), and Raffer (2016). See also Brooks and Lombardi (2015), Gelpern (2015), and Guzman and Stiglitz (20I5c).

39. For a more extensive discussion of this problem, see Stiglitz (2002b).

\section{REFEREN CES}

Barr, David, Oliver Bush, and Alex Pienkowski. 20I4. "GDP-linked Bonds and Sovereign Default." Working Paper No. 484, Bank of England, London.

Blackman, Jonathan I., and Rahul Mukhi. 2010. "The Evolution of Modern Sovereign Debt Litigation: Vultures, Alter Egos, and Other Legal Fauna." Law \& Contemporary Problems 73: 47 .

Brooks, Skylar, Martin Guzman, Domenico Lombardi, and Joseph E. Stiglitz. January 20I5. "Identifying and Resolving Inter-Creditor and Debtor-Creditor Equity Issues in Sovereign Debt Restructuring." Center for International Governance Innovation Policy Brief No. 53.

Brooks, Skylat, and Domenico Lombardi. 2015. "Governing Sovereign Debt Restructuring Through Regulatory Standards." Paper presented at the Initiative for Policy Dialogue-Center for International Governance Innovation Conference on Sovereign Debt Restructuring at Columbia University, New York, September 22.

—_. 2016. "Private Creditor Power and the Politics of Sovereign Debt Governance." In Too Little, Too Late: The Quest to Resolve Sovereign Debt Crises, ed. Martin Guzman, José Antonio Ocampo, and Joseph E. Stiglitz, chapter 3. New York: Columbia University Press.

Chatterjee, Satyajit and Burcu Eyigungor. 2015. "A Seniority Arrangement for Sovereign Debt." American Economic Review I05 (no. 12): 3740-3765.

Chodos, Sergio. 2016. "From the Pari Passu Discussion to the 'Illegality' of Making Payments." In Too Little, Too Late: The Quest to Resolve Sovereign Debt Crises, ed. Martin Guzman, José Antonio Ocampo, and Joseph E. Stiglitz, chapter 4. New York: Columbia University Press.

Conn, Richard A., Jr. 2016. "Perspectives on a Sovereign Debt Restructuring Framework: Less Is More." In Too Little, Too Late: The Quest to Resolve Sovereign Debt Crises, ed. Martin Guzman, José Antonio Ocampo, and Joseph E. Stiglitz, chapter 13. New York: Columbia University Press.

Eichengreen, Barry, and Ashoka Mody. 2003. "Is Aggregation a Problem for Sovereign Debt Restructuring?" American Economic Review 93 (no. 2): 80-84.

Gelpern, Anna. 2015. "What Is Wrong with Sovereign Debt Restructuring and How to Fix It." Paper presented at the Initiative for Policy Dialogue-Center for International Governance Innovation Conference on Sovereign Debt Restructuring at Columbia University, New York, September 22.

Gelpern, Anna, Ben Heller, and Brad Setser. 2015. "Count the Limbs: Designing Robust Aggregation Clauses in Sovereign Bonds." Paper presented at the Initiative for Policy Dialogue-Center for International Governance Innovation Conference on Sovereign Debt Restructuring at Columbia University, New York, September 22 
Greenwald, Bruce C., and Joseph E. Stiglitz. 1986. "Externalities in Economies with Imperfect Information and Incomplete Markets." Quarterly Journal of Economics IOI (no. 2): 22.9-264.

Guzman, Martin. November 2014. "Understanding the Relationship Between Output Growth Expectations and Financial Crises." Columbia University Initiative for Policy Dialogue Working Paper, New York.

Guzman, Martin, and Joseph E. Stiglitz. 2014a. "Pseudo-wealth and Consumption Fluctuations." Columbia University Working Paper, New York.

- 20I4b. "Argentina’s Griesafault." Project Syndicate, August 7.

- 2014c: "Debeaking the Vultures." Project Syndicate, October I.

—. 20I5a. "Pseudo-wealth Fluctuations and Aggregate Demand Effects." Columbia University Working Paper, New York.

- 2015b. "A Fair Hearing for Sovereign Debt." Project Syndicate, March 5.

. 20I5c. "A Rule of Law for Sovereign Debt." Project Syndicate, June I5.

. 20I5d. "A Theory of Pseudo-Wealth." In Contemporary Issues in Macroeconomics: Lessons from the Crisis and Beyond, ed. J. E. Stiglitz and M. Guzman, chap. I. Palgrave, London.

Hellenic Statistical Authority Labor Force Survey. 2015. Press release. www.statistics .gr/portal/page/portal/ESYE/BUCKET/Aoror/PressReleases/AoroI_SJOO2 DT_MM_OI_2OI5_OI_F_EN.pdf.

Herndon, Thomas, Michael Ash, and Robert Pollin. 2or4. "Does High Public Debt Consistently Stifle Economic Growth? A Critique of Reinhart and Rogoff." Cambridge Journal of Economics 38 (no. 2): 257-279.

Herman, Barry. "Toward a Multilateral Framework for Recovery from Sovereign Insolvency." In Too Little, Too Late: The Quest to Resolve Sovereign Debt Crises, ed. Martin Guzman, José Antonio Ocampo, and Joseph E. Stiglitz, chapter II. New York: Columbia University Press.

Howse, Robert. "Toward a Framework for Sovereign Debt Restructuring: What Can Public International Law Contribute?" In Too Little, Too Late: The Quest to Resolve Sovereign Debt Crises, ed. Martin Guzman, José Antonio Ocampo, and Joseph E. Stiglitz, chapter I4. New York: Columbia University Press.

International Capital Markets Association. 2014. "Standard Collective Action and Pari Passu Clauses for the Terms and Conditions of Sovereign Notes." http:/www icmagroup.org/resources/Sovereign-Debt-Information/

International Monetary Fund, October 2014. "Strengthening the Contractual Framework to Address Collective Action Problems in Sovereign Debt Restructuring." https:/www.imf.org/external/np/pp/eng/20I4/0902I4.pdf

Jordà, Òscar, Moritz H. P. Schularick, and Alan M. Taylor. 2013. "Sovereigns Versus Banks: Credit, Crises, and Consequences." Working Paper No. 19506, Cambridge, Mass.: National Bureau of Economic Research.

Kaiser, Jürgen. 2016. "Making a Legal Framework for Sovereign Debt Restructuring Operational." In Too Little, Too Late: The Quest to Resolve Sovereign Debt Crises, ed. Martin Guzman, José Antonio Ocampo, and Joseph E. Stiglitz, chapter 12. New York: Columbia University Press. 
Krueger, Anne. 200I. "International Financial Architecture for 2002: A New Approach to Sovereign Debt Restructuring." American Enterprise Institute, Washington, D.C., November 26.

Li, Yuefen. 2016. "The Long March Towards an International Legal Framework for Sovereign Debt Restructuring." Forthcoming, Journal of Globalization and Development.

Miller, Marcus, and J. E. Stiglitz. I999. "Bankruptcy Protection Against Macroeconomic Shocks: The Case for a 'Super Chapter In." World Bank Conference on Capital Flows, Financial Crises, and Policies, Washington, D.C., April I5.

-. 2010. "Leverage and Asset Bubbles: Averting Armageddon with Chapter Ir?" Economic Journal $\mathrm{I} 2 \mathrm{O}$ (no. 544): 500-518.

Mooney, Charles W. Jr. 2015. "A Framework for a Formal Sovereign Debt Restructuring Mechanism: The KISS (Keep It Simple, Stupid) Principle and Other Guiding Principles." 37 Michigan Journal of International Law 37.

Newbery, David MG, and Joseph E. Stiglitz. 1982. "The choice of techniques and the optimality of market equilibrium with rational expectations." Journal of Political Economy 90 (no. 2): 223-246.

Ocampo, José Antonio. 2016. "A Brief History of Sovereign Debt Resolution and a Proposal for a Multilateral Instrument." In Too Little, Too Late: The Quest to Resolve Sovereign Debt Crises, ed. Martin Guzman, José Antonio Ocampo, and Joseph E. Stiglitz, chapter 1o. New York: Columbia University Press.

Orszag, Peter, and Joseph Stiglitz. 2002. "Optimal Fire Departments: Evaluating Public Policy in the Face of Externalities." Brookings Institution, Washington, D.C., January 4 .

Raffer, Kunibert. 1990. "Applying Chapter 9 Insolvency to International Debts: An Economically Efficient Solution with a Human Face." World Development I8 (no. 2): 30I-313.

—. 2015. "Debts, Human Rights, and the Rule of Law: Advocating a Fair and Efficient Sovereign Insolvency Model." Columbia University Initiative for Policy Dialogue Working Paper, New York.

- - 2016. "Debts, Human Rights, and the Rule of Law: Advocating a Fair and Efficient Sovereign Insolvency Model." In Too Little, Too Late: The Quest to Resolve Sovereign Debt Crises, ed. Martin Guzman, José Antonio Ocampo, and Joseph E. Stiglitz, chapter I5. New York: Columbia University Press.

Reinhart, Carmen M., and Kenneth S. Rogoff. 20Io. "Growth in a Time of Debt (Digest Summary)." American Economic Review 100 (no. 2): 573-578.

Schumacher, Julian, Christoph Trebesch, and Henrik Enderlein. 2014. "Sovereign Defaults in Court." http://papers.ssrn.com/sol3/papers.cfm?abstract_id=2189997.

Stiglitz, Joseph E. 1985. "Information and Economic Analysis: A Perspective." Economic Journal 95 (Supplement): 2I-4I.

- 1998. "Knowledge for Development: Economic Science, Economic Policy, and Economic Advice." In Annual World Bank Conference on Development Economics, ed. B. Pleskovic and J. Stiglitz, 9-58. Washington, D.C.: World Bank.

2.. 2002a. "Sovereign Debt: Notes on Theoretical Frameworks and Policy Analyses." Columbia University Initiative for Policy Dialogue Working Paper Series, New York. 
2002b. Globalization and Its Discontents. New York: Norton. 2006. Making Globalization Work. New York: Norton.

. 2010a "Sovereign Debt: Notes on Theoretical Frameworks and Policy Analyses." In Overcoming Developing Country Debt Crises, ed. B. Herman, J. A. Ocampo, and S. Spiegel, 35-69. Oxford: Oxford University Press.

- 2oIob. Freefall: America, Free Markets, and the Sinking of the World Economy, New York: Norton.

- 2014. "Crises: Principles and Policies: With an Application to the Eurozone Crisis." In Life After Debt: The Origins and Resolutions of Debt Crisis, ed. Joseph E. Stiglitz and Daniel Heymann, 43-79. Houndmills, UK.

Stiglitz, Joseph E., Martin Guzman, Domenico Lombardi, José Antonio Ocampo, and Jan Svejnar. 2015. "Frameworks for Sovereign Debt Restructuring." Columbia Initiative for Policy Dialogue-Center for International Governance InnovationCenter on Global Economic Governance Policy Brief, January 26.

Stiglitz, Joseph E., et al. 2oro. The Stiglitz Report: Reforming the International Monetary and Financial Systems in the Wake of the Global Crisis, with Members of the Commission of Experts on Reforms of the International Monetary and Financial System appointed by the President of the United Nations General Assembly, New York: New Press

Townsend, Robert M. 1979. "Optimal contracts and competitive markets with costly state verification." Journal of Economic Theory 2I (no. 2): 265-293. 